\title{
ANALYSIS OF LABOR PRODUCTIVITY RESPONSE OF INDEPENDENT PALM OIL PLANTATION TOWARDS PRICE FLUCTUATION OF FRESH FRUIT BUNCH IN BANYUASIN REGENCY
}

\author{
Lifianthi*, Yunita, Rosana Elly \\ Master's Program in Agribusiness, Faculty of Agriculture, University of Sriwijaya, Indonesia \\ *E-mail: llifianthi@yahoo.co.id
}

\begin{abstract}
Analysis of Labor Productivity Response of Independent Palm Oil Plantation towards Price Fluctuation of Fresh Fruit Bunch (FFB) in Banyuasin Regency. A study which examined how independent farmers manage their allocated working time on their palm oil plantation. One of the production factors to be analyzed was the factor of labor productivity which has an important role in every farming activity. Measuring the labor productivity in managing independent palm oil plantations, whether it can be managed and utilized properly to achieve optimal results, can be attributed to the development of fluctuating FFB prices. In the last few years, some agricultural commodities which have export value such as palm oil had fluctuating selling prices, where the CPO selling price was influenced by the world crude oil price of which automatically impacted the price of FFB received by palm oil farmers. The study was conducted in the Banyuasin Regency area. The data from primary and secondary sources of independent palm oil farmers, i.e. the sample characteristics, plantation area, production, costs of production factors, number of labor, labor costs and the selling price of FFB. Thus this study was examine how labor productivity response of independent plantation towards price fluctuation of FFB analyzed by the income of independent farmers, the FFB production, and the production costs using the regression equation analysis model approach. Then it was discussed descriptively how independent farmers managing their palm oil plantations.
\end{abstract}

\section{KEY WORDS}

Fluctuation, palm oil, labor, plantation.

The current fluctuating price of FFB forces many farmers to abandon their palm oil plantations and turn into other businesses to meet their daily needs. Increasing land clearing for palm oil plantation increases the production of palm oil fresh fruit bunches (FFB) every year. Production that continues to increase is not in line with the price of FFB itself which fluctuates, thus the fluctuating prices resulting in unstable income of the farmers. This is what forces independent farmers to find other jobs to supplement their income so that they can meet their daily needs. Independent palm oil farmers do this as one of the alternative ways to meet their daily needs that are no longer balanced with the income from selling the palm oil they produced.

The decline in global crude oil prices certainly affects the CPO selling price in the world market and will affect the amount of CPO production in Indonesia, as well as being influenced by other vegetable oil production which controls the vegetable oil market in mainland Europe. Since the beginning of 2015, with fluctuating CPO prices will certainly affect the production of palm oil from both palm oil companies and palm oil farmers who seek and rely their livelihood from these palm oil commodities.

Government policies regarding the imposition of export tax also affect the selling price of Fresh Fruit Bunches (FFB) at the farmer level. The imposition of export tax has led to speculation among CPO exporters by anticipating average CPO prices. Exporters observed CPO prices in Rotterdam of the last few weeks, then set FFB prices for the farmer level before the government determined how much the export tax should be set. This also resulting in the CPO prices in Indonesia to fall first, while CPO price on the international 
market is still high. The effect of falling CPO prices in Indonesia will cause a decrease in the selling price of FFB at the farmer level (Bank Indonesia, 2015).

Palm oil plantations in Banyuasin Regency which are run by independent farmers, where the business of palm oil plantations requires good management. The availability of the production factors which will later affect the livelihood of the farmers. One of the production factors of which has an important role is labor. Labor productivity in palm oil is the ratio of palm oil production to the total labor productivity in palm oil. The productivity of palm oil is most responsive to changes in labor productivity compared to other factors in palm oil plantations. This shows that labor is a very important factor in palm oil production (Wildayana, 2013).

According to Szelag-Sikora et al. (2015) labor productivity often determines the orientation of production, intensity of agriculture, and investment in agriculture activities mainly oriented to reducing works in difficult conditions and increasing profitability of production. Knowledge of labor resources, assets and potential for agriculture production, can be rationally modernized and developed in accordance with the principles of sustainable development. The utilization of workers who come from within the family is usually more efficient than using workers who come from outside the family (labor). Labor ( man power) is the working age population (aged 15-64 years), or the entire population of a country who produce goods and services if there is a demand for their labor and if they want to participate in such activities (Mulyadi,2003).

Given the number independent farmers whose lives depend on palm oil plantations in Banyuasin Regency, then this condition is interesting and relevant to be studied more deeply on how management and labor productivity of independent palm oil farmers, in relation to the price fluctuation of FFB. The palm oil farm households in each period will receive income from the ownership of the palm oil production. This income can be received daily, weekly, monthly or annually.

To balance the daily needs of palm oil farm households, independent farmers carry out adjustment in their business even though the price of FFB experiences fluctuations. The way to do this is by increasing labor productivity which involves mechanization, addition of human resources and investment / capital.

\section{LITERATURE REVIEW}

Mingorria et al, (2014), conducted socio-economic research of household in Q'eqchi in Guatemala where farm area affected the working time of men and women labors. Agricultural activities if considered as an industrial activity (Nakajima, 1986) can be grouped into 3 (three) main characteristics; 1) Characteristics of agricultural production technology, 2) Characteristics of farm households as an economic unit, and 3) characteristics of agricultural products as a commodity which focused only on farm households.

Research conducted by Jacoby (1992) on men and women labor productivity on subsistence agriculture in Peruvian Sierra, Peru, agriculture in Sierra were cultivating various crops and raising livestock. The results of this study indicated that male and female labors complemented each other, where an increase in working hours would increase the marginal product of others, as well as the household's decision to employ male and female labors in families inside and outside agriculture. The productivity of male labor was greater than female labor.

Lifianthi, et al (2018), suggested the role of family labor is less noticeable in the management of palm oil farming. Independent farmers tend to employ more family labor or manage their own farming. This is influenced by the still productive age factor. But when harvesting time, they employed labor outside the family.

Kawagoe and Hayami (1983) in Sharma et al.(1990) found differences in productivity in developed and developing countries. Comparisons were made on the partial productivity of production two factors, land area and labor. Productivity was compared from time to time during the 1975- 1980 period in different regions. Land area and labor productivity were 
believed to be closely related and the level of productivity of one of these factors affected the productivity of the other.

Related to the price of FFB in Mukmin's research (2016), the decline in the price of palm oil had a very bad impact on the socio-economic life of the community. Farmers who rely on the palm oil plantation as their main livelihood were faced with economic problems of the decline in oil palm commodity prices. The price decline was very significant, resulted in the reduced level of income and their overall welfare. Although farmers still have income from their production, but with lower oil prices, they admitted that their income was not sufficient to meet the daily needs of their families. Price fluctuation that often occurred are very influential on the labor productivity of palm oil farmers in terms of managing their palm oil plantation.

\section{METHODS OF RESEARCH}

The research was carried out in the territory of Banyuasin Regency, on the independent palm oil plantation. The location selection was done deliberately or purposive sampling. Data collected were primary data and secondary data. Primary data collection was done by direct observation in the field and interviews with respondents using questionnaire instruments. Whereas secondary data was obtained from the agencies involved in this study, including the South Sumatra Plantation Office, the Plantation Services in the regency, and the Central Statistics Agency. Secondary data was also obtained through literature and other data sources that support this research.

Random sampling technique used was layered proportional (Proportioned Stratified Random Sampling). This sampling technique was used because the population's sample of the palm oil farmers was independent palm oil farmers. Sampling was done with returns and or without returns. This was done so there would be no recurring samples or multiple samples thus the results obtained in this study would be more accurate (Nasution, 2003). This method was utilizing a random number table. Determination of the number of the samples was carried out using the following Slovin method:

$$
\begin{gathered}
\mathrm{N} \\
\mathrm{n}=\mathrm{N}(0,15)^{2}
\end{gathered}
$$

Where: $\mathrm{n}=$ Number of Samples; $\mathrm{N}=$ Number of population; $\mathrm{e}=$ The research error rate or level by $15 \%$ or 0,15 .

Sample chosen from the population represented the independent palm oil farmers in Banyuasin Regency. To answer all research objectives, mathematical operational models were used to describe in detail for each research objectives.

To answer the first objective; analyzing allocated working time of the independent farmers in the maintenance of palm oil farming activities, then the analysis using the following equation:

$$
\begin{aligned}
& \text { Total of Working Days }=\text { Number of Labors }(\mathrm{OK}) \times \text { Working Days }(\mathrm{HK}) \\
& \text { Total of Working Days }=\sum \mathrm{HK} \times \text { Working Hours } \\
& \text { Allocated working time }=\sum(\mathrm{OK} \times \mathrm{HK} \times \mathrm{JK})
\end{aligned}
$$

Conversion factors of female and child labor are comparable with male workers:

$$
\begin{aligned}
& n w=\cdot \frac{J k w}{J k p} \\
& n a=\frac{J k a}{J k p}
\end{aligned}
$$


Where: $n_{w}$ - Coefficient of female labor is equal to male labor; $n_{a}$ - Coefficient of child labor is equals male labor; Jkw, Jka, Jkp - women labor working hours, child labor working hours, male labor working hoursper day.

To answer the second objective; analyzing the labor productivity of independent palm oil farmer son the price fluctuation of fresh fruit bunches (FFB) was calculated using the following equation (Hunt, 2000):

$$
P T K=\frac{0}{C T K}
$$

Where: PTK - Labor productivity (Kg / hectare / HOK); O - Output in the form of FFB production ( $\mathrm{kg} /$ hectare); CTK - Allocated working time (HOK).

To answer the third objective; analyzing fluctuations of the FFB selling price on the productivity of independent farmers using following equation:

$$
Y=f\left(X_{1}, X_{2}, X_{3}, \ldots, X_{n}\right)
$$
2006):

The basic model of the linear regression equation as follows (Cooper and Schindler,

$$
Y_{i}=\beta_{0}+\beta_{1} X_{i}
$$

Because the independent variables were more than one, the equation above was developed into a linear regression model as follows:

$$
Y_{i}=\beta_{0}+\beta_{1} X_{i}+\varepsilon
$$

Where: $Y_{i}$ - Labor productivity of palm oil plasma farmers $(\mathrm{Kg} / \mathrm{HOK}) ; X_{i}$ - Income $(\mathrm{Rp} /$ year); $\varepsilon$ - error term.

For slope, $\beta 1$ was used as the following formula:

$$
\beta_{1}=\frac{\Delta Y}{\Delta X}
$$

The above linear regression model was then translated into the quadratic regression equation as follows (Pindyck and Rubinfeld, 1998):

$$
Y_{K S}=\beta_{0}+\beta_{1} X_{1}+\varepsilon
$$

Where: $Y$ ks - Labor productivity of independent palm oil farmers ( $\mathrm{Kg} \mathrm{/} \mathrm{HOK}$ ); $\beta_{0}$ - Interception; $\beta_{1}, \beta_{2, \ldots} \beta_{4}-$ Slope; $X_{1}=P_{d_{T B S}}$ : Income (Rp / year).

To find out whether the data were normally distributed, the $z_{\text {hitung }}$ formula was used (Riduwan, 2010):

$$
z_{\text {hitung }}=\frac{\bar{x}-\mu_{0}}{\frac{\sigma}{\sqrt{N}}}
$$

Where: $z_{\text {hitung }}$ - Calculated price and the standard deviation value in the normal distribution (table $z$ ); $\bar{x}$ - Average value obtained from the results of data collection; $\mu_{0}$ - Average value hypothesized; $\sigma$ - Known standard deviation of the population; $\mathrm{N}$ - Total population. 
To determine the accuracy of the model to calculate the coefficient of determination $\left(R^{2}\right)$ : the size of the suitability of the regression line of the data, or indicate the proportion of the total variation of the dependent variable explained by a single independent variable (Mulyono, 2006).

To find out whether the independent variables as a whole affect the independent variables with the F test:

$$
F_{\text {hitung }}=\frac{\frac{R^{2}}{k}}{\frac{\left(1-R^{2}\right)}{n-k-1}}
$$

Where: $\mathrm{R}$ - Multiple correlation coefficient values; $\mathrm{K}$ - Number of independent variables (independent); $\mathrm{N}$ - Total samples; $F_{\text {hitung }}$ - The value of $\mathrm{F}$ calculated.

Analysis was based on the following hypothesis:

- $\mathrm{H}_{0}: \mathrm{b}_{\mathrm{i}}=0$;

- $\mathrm{H}_{\mathrm{a}}$ : at least one of the independent variables $\neq 0$.

Decision Rules:

- If $\mathrm{F}_{\text {hitung }} \geq \mathrm{F}_{\text {table }}$, then $\mathrm{H}_{0}$ is rejected, $\mathrm{H}_{\mathrm{a}}$ is accepted, meaning that there is a significant influence of the independent variables on the dependent variable.

- If $\mathrm{F}_{\text {hitung }} \leq \mathrm{F}_{\text {table, }}$, then $\mathrm{H}_{0}$ is accepted, $\mathrm{H}_{\mathrm{a}}$ is rejected, meaning that there is no significant influence of independent variables on the dependent variable.

To find out whether each independent variables influences the dependent variable with the t test:

$$
t_{\text {hitung }}=\frac{b_{i}}{S e\left(b_{i}\right)}
$$

Where: $b_{i}-$ The , regression coefficient of the estimated model; $S b_{i}-b_{i}$ standard deviation; $t_{\text {table }}-\mathrm{t}(\alpha / 2 ;(\mathrm{n}-\mathrm{k}-1))$.

Analysis was based on the following hypothesis:

- $\mathrm{H}_{0}: \mathrm{b}_{\mathrm{i}}=0$;

- $\mathrm{H}_{\mathrm{a}}$ : at least one of the independent variables $\neq 0$.

Decision Rules:

- If $t_{\text {hitung }}>t_{\text {table, }}$, then $\mathrm{H}_{0}$ is rejected, $\mathrm{H}_{\mathrm{a}}$ is accepted, meaning that there is a significant influence of the independent variables on the dependent variable;

- If $t_{\text {hitung }}<t_{\text {table }}$, then $\mathrm{H}_{0}$ is accepted, $\mathrm{H}_{\mathrm{a}}$ is rejected, meaning that there is no significant influence of independent variables on the dependent variable.

To answer the fourth objective; to compile and formulate a descriptive policy strategy from the analysis and calculation of first to third objective, a policy strategy formulation in palm oil plantations was carried out by independent palm oil farmers associated with price fluctuation of FFB in Banyuasin Regency.

\section{RESULTS AND DISCUSSION}

The working time of palm oil farming activities by independent farmers was around 7 and 8 in the morning until 12 noon even there were some farmers until $1 \mathrm{pm}$. The average working time spent by independent farmers in each farming activity was around 4 to 6 hours a day. Palm oil farming activities assisted by family members, wives and children.

The palm oil farming activities by independent farmers on average were $25.29 \mathrm{HOK}$ per year, the amount of time devoted by independent farmers were low, because independent farmers not only did palm oil farming activities, but they also did other business activities. 
The average land area of independent palm oil farms was 2.27 hectares of land. Fertilization activities were carried out only twice a year. Pest and disease control activities were carried out twice a year, meanwhile maintenance activities of cleaning the plantations was only based on the condition of the plantations, if the weed plants were getting tall, then the cleaning activities was done. Harvesting of FFB yields was carried out twice a month. The harvests then transported to the place of collection.

Table 1 - Average Allocated Working Time Family of Independent Farmers

\begin{tabular}{clll}
\hline No. & Independent Farmer Activities & HOK / yr & Percentage (\%) \\
\hline 1 & Maintenance & 2.42 & 9.57 \\
2 & Fertilization & 1.36 & 5,38 \\
3 & Pests and diseases control & 3.09 & 12.21 \\
4 & Harvesting & 6.16 & 24.35 \\
5 & Transporting harvests & 12.27 & 48.50 \\
\hline & Total & 25.29 & 100.00 \\
\hline
\end{tabular}

Based on Table 2.below, the productivity of palm oil plantations in Sungai Rengit Village with the average plant age of 24-25 years was much smaller than the productivity of palm oil plantations with the plant age of 12 years during the peak productivity period of palm oil plants.

Table 2 - Average Production and Productivity of Independent Palm Oil Plantations of the Plant Age of 12 Years and 24-25 Years

\begin{tabular}{ccccc}
\hline No & Description & Peak Productivity & Post-Declining Productivity $^{\star *}$ & Difference \\
\hline 1 & Production (kg / ha / yr) & $47,930.70$ & $34,892.50$ & $13,038.20$ \\
2 & Land Area (Ha) & 2.27 & 2.27 & \\
3 & Productivity (kg / ha / yr) & $21,145.89$ & $15,393.75$ & $5,752.14$ \\
\hline
\end{tabular}

* Period from July 2017 to June 2018;

** Period from October 2018 to September 2019.

After calculating the productivity of palm oil plantations, the productivity of independent palm oil labors was also calculated. The labor productivity was the comparison between the total of fresh fruit bunches produced by farmers and the total number of labor used.

Table 3 below showed that the peak productivity of FFB had an impact on the labor productivity of independent palm oil plantation. The average allocated working time when the peak productivity of FFB was 1,895.24 HOK per year ,meanwhile when the post-declining productivity of FFB was 1,379.69 HOK per year with a difference of $515.55 \mathrm{HOK}$ per year. Farming activities of independent palm oil farmers were maintenance, fertilization, pests and diseases control, harvesting and transportation of the harvests. The average number of labors was 3-4 people with the highest number being 11.23 or around 12 people.

Table 3 - Productivity of Independent Farmers

\begin{tabular}{ccccc}
\hline No. & Description & Peak Productivity * & Post-Declining Productivity ** & Difference \\
\hline 1 & Production (kg / ha / yr) & $47,930.70$ & $34,892.50$ & 13038.20 \\
2 & Number of Workers (HOK / Yr) & 25.29 & 25.29 & \\
3 & Productivity (HOK / Yr) & $1,895.24$ & $1,379.69$ & 515,55 \\
\hline
\end{tabular}

* Period from July 2017 to June 2018;

** Period from October 2018 to September 2019.

To find out the average income from the farming activities of independent palm oil farmers when peak productivity and post-declining productivity of palm oil was by calculating the total revenue minus the total cost of palm oil farming. The results of the average income calculation can be seen in Table 4 below:

Based on Table 4, the average income per year of the post-declining productivity in Sungai Rengit Village was Rp.18,453,244.73 per hectare per year, while peak productive 
palm oil plants in Sungai Rengit Village with average income of Rp.41.976,789.40 per hectare per year with a difference of Rp23,523,544.67 per hectare per year or around 56.04 percent.

Table 4 - Average Revenue, Production Costs, and Income

\begin{tabular}{llrrr}
\hline No. & Description & Peak Productivity * & \multicolumn{1}{c}{$\begin{array}{c}\text { Post-Declining } \\
\text { Productivity }\end{array}$} & \multicolumn{1}{c}{ Difference } \\
\hline 1 & Revenue & $49,943,789.40$ & $22,825,277.80$ & $27,118,511.60$ \\
2 & Production cost & $7,967,000.00$ & $4,372,033.07$ & $3,594,966.93$ \\
3 & Income & $41,976,789,40$ & $18,453,244.73$ & $23,523,544.67$ \\
\hline
\end{tabular}

${ }^{*}$ Period from July 2017 to June 2018;

** Period from October 2018 to September 2019.

Farmers' income in Sungai Rengit Village was decreased due to the not optimal production of FFB because old and unproductive plants aged 24-25 years compared to 12 years old productive palm oil plants. In addition, there was also lack of care and maintenance provided by independent farmers to their plantation. The decline of productivity has resulted in the decline of income generated by independent farmers. The decline was significant compared to when the age of the palm oil plants was still productive.

The decline of income earned by independent farmers was also because the decrease in the selling price of FFB. Beside the fluctuating selling price of FFB, the low quality of FFB produced by farmers resulted in the low selling price of FFB. The average selling price of FFB was very different between FFB peak productivity and FFB post-declining productivity. The selling price of FFB was Rp.1,042.

Post-declining productivity and income of palm oil or the low results of FFB cultivated by independent farmers had an impact on the reduction of allocated working time on their palm oil farming activities. This because their palm oil plantations have not been productive anymore in producing the FFB, therefore to cover their daily needs after the decline in palm oil productivity; they were forced to do alternative activities outside of palm oil farming.

The method in analyzing the influence of labor productivity on income was by using a simple regression model. The results of the regression analysis during the peak and postdeclining productivity of FFB of independent palm oil farmers were equally positive. Table 5 were the results of the regression analysis of the independent farmers' labor productivity to their income during peak productivity FFB period, which showed that the income variable with a significant value of 0,000 , smaller than $\alpha=0.05$ with a coefficient of 7.196. The coefficient value of the labor productivity variable had significant influence to the income variable. The positive value of the coefficient of income variable has a positive influence on the labor productivity of independent farmers. If the income of independent palm oil farmers has increased by Rp1, - per year, then there will be an increase in labor productivity by 7.196 percent HOK per year during the post-declining productivity of FFB period. In detail can be observed in Table 5.

Table 5 - Results of Regression Analysis of the Labor Productivity of Independent Palm Oil Farmer on Their income in Sungai Rengit Village during the Peak Productivity Period of FFB

\begin{tabular}{llll}
\hline \multicolumn{1}{c}{ Variable } & \multicolumn{1}{c}{ Estimated Parameter (B) } & \multicolumn{1}{c}{$t_{\text {hitung }}$} & Sig. \\
\hline (Constant) & $-4135719,686$ & $-29,475$ & 0,000 \\
Income & 7,196 & 2,188 & 0,000 \\
R Square $=0.999$ & & R Adj $=0.999$ & \\
Durbin Watson =2,175 & & & \\
F Statistics = 47898,970 & & & \\
\hline
\end{tabular}

The results of the regression analysis of the independent farmers' labor productivity to their income during post-declining productivity FFB period, which showed that the income variable with a significant value of 0,013 , smaller than $\alpha=0.05$ with a coefficient of 2.596 . The coefficient value of the labor productivity variable had significant influence to the income variable. The positive value of the coefficient of income variable has a positive influence on 
the labor productivity of independent farmers. If the income of independent palm oil farmers has increased by Rp1, - per year, then there will be an increase in labor productivity by 2.596 percent HOK per year during the peak productivity of FFB period. In detail can be observed in Table 6.

Based on the results of regression analysis between labor productivity of independent palm oil farmers and their income in 2 periods of peak and post-declining FFB productivity, had positive effect. These results indicated that the income of independent palm oil farmers determined the productivity of their labor. If the income of independent farmers was high, allocated working time of the labor productivity decreased and vice versa if their income was low, allocated working time of the labor productivity increased.

Table 6 - Results of Regression Analysis of the Labor Productivity of Independent Palm Oil Farmer on Their income in Sungai Rengit Village during the Post-Declining Productivity Period of FFB

\begin{tabular}{llll}
\hline \multicolumn{1}{c}{ Variable } & \multicolumn{1}{c}{ Estimated Parameter (B) } & \multicolumn{1}{c}{$t_{\text {hitung }}$} & Sig. \\
\hline (Constant) & 43789414,472 & 46,462 & 0,000 \\
Income & 2,596 & 2,666 & 0.013 \\
\hline R Square $=0.202$ & R Adj $=0,174$ & \\
Durbin Watson $=0,901$ & & & \\
F Statistics $=7,107$ & & & \\
\hline
\end{tabular}

Based on the results of research, there are some policy and strategies that can be done by independent palm oil farmers relating to palm oil farming activities in South Sumatra as follows:

- Maintaining a stable FFB level of productivity with the better plantation management (weed clearing, pruning, and cleaning), fertilizing, pests and diseases control, and harvesting;

- Improving facilities and infrastructure for palm oil plants, the plantation, and their management by following good palm oil cultivation techniques;

- The need for independent farmers to think about the sustainability of their plantation cycles through the rejuvenation of their palm oil plantations because the investment required is not small and allocates their palm oil expenditures for the rejuvenation;

- Empowerment and improvement of the quality of human resources and institutional groups of farmers and cooperatives in order to be able to collaborate and work together with the fellow farmers in managing their palm oil so that they can always produce highest palm oil potential;

- Improving independent farmers' income management, because palm oil often experience price fluctuations, so that when farmers' income decreases or FFB productivity decreases, farmers are still biased to meet their daily needs;

- Reducing allocated working time of labor outside the family, thus reducing production costs to pay the labor;

- Price determination of FFB produce by the government which reasonable and fair for both parties.

\section{CONCLUSION}

The conclusions based on the research results are: Allocated working time of palm oil farming activities by independent farmers averaging $25.29 \mathrm{HOK}$ per year, the amount of time devoted by independent farmers was not that much because independent farmers carry out other business activities beside palm oil farming activities. The allocated working time of peak productivity period averaging 1,895.24 HOK per year while for post-declining productivity period averaging 1,379.69 HOK per year with a difference of $515.55 \mathrm{HOK}$ per year. The income of post-decreasing productivity period averaging Rp. 18,453,244.73 per hectare per year, while peak productive period, averaging income of Rp. 41,976,789.40 per hectare per year with a difference of Rp. 23,523,544.67 per hectare per year or around 56.04 percent. Regression results showed that the income of independent farmers was high, 
allocated working time of the labor productivity decreased and vice versa if their income was low, allocated working time of the labor productivity increased.

The suggestions that can be given based on the results of research are as follows: It is advisable to provide guidance to independent farmers in cultivating palm oil plants so that farmers become more active cultivating palm oil plants, because the land area of independent farmers plantation are still very small. Independent farmers when productivity decreases, low income, meanwhile have much free time, therefore farmers are expected to optimize the available free time. For further researchers to compare the labor's allocated working time of contract farmer with the labor's allocated working time of independent farmers.

\section{REFERENCES}

1. Bank Indonesia. 2015. The Impact of Determination of CPO Export Tax on FFB Prices ( http://www.bi.go.id/id/publikasi/ kajian - ekonomi - regional / bengkulu / Documents / 7228d9e9f8bb448eb50e5691ca596e2 Box 1 Impact of PECPO.pdf Determination). (Access on September 12, 2016).

2. Hunt, R. C. 2000. Labor Productivity and Agricultural Development: Boserup Revisited. Hum Ecology. 28 (2): 251 - 276. Springer (Accessed on 28 September 2016).

3. Jacoby, H. G. 1992. Productivity of Men and Women and the Sexual Division of Labor in Agriculture of the Peruvian Sierra. J. Dev. Econ.37 (1-2): 265 - 287. Elsevier (Accessed on October 16, 2016).

4. Lifianthi, S. Oktarina, E. Rosana, and S. D Wulan. 2018. Factors that Influence Allocation of Employee Time Towards Palm Oil Productivity For Plasma Farming In The District of Musi Banyuasin. RJOAS, 8 (80), August 2018. DOI http://doi.org/10.1855/rjoas.201808.44 .

5. Mingorria, S., Gamboa, G., Lopez, B. M. and Corbera, E. 2014. The palm oil Boom: Socio-Economic Implications for Q'eqchi 'households in the Polochic Valley, Guatemala. Environ. Dev Sustain. 16 (4): 1 - 31. Springer. (Accessed September 13, 2016).

6. Mulyadi, S. 2003. Human Resource Economics in a Development Perspective. Rajagrafindo Persada, Jakarta.

7. Mukmin, P. 2016. The Impact of Palm Oil Price Declines on the Welfare of Palm Oil Farmers on the East Coast of North Sumatra. Medan: Lecturer Research at the Faculty of Economics, Muhammadiyah University, North Sumatra.

8. Mulyono, S. 2006. Statistics for Economics and Business. University of Indonesia Faculty of Economics Publisher Institute, Jakarta.

9. Nasution, R. 2003. Sampling Techniques: Teaching Materials Faculty of Public Health, University of North Sumatra. Digitized by USU Digital Library.

10. Pindyck, R. S. and Rubinfeld, D. L. 1998. Econometric Models and Economic Forecast. McGraw-Hill Book Co., Singapore.

11. Riduwan. 2010. Statistics for Economics and Business. University of Indonesia Faculty of Economics Publisher Institute, Jakarta.

12. Sharma, K. C., Prasada Rao, D. S. and Shepherd, W. F. 1990. Productivity of Agricultural Labor and Land: An International Comparison. Agric Econ. 4 (1): 1-12. Elsevier Science Publisher B. V. Amsterdam. (Accessed September 24, 2016).

13. Szelag-Sikora, A., Cupial, M. and Niemiec, M. 2015. Intensity and Labor Consumtion of Integrated Production in Horticultural Farms. Agric and Agric. Sci Procedia. 7: 249-250. Elsevier Science Ltd. (Accessed September 11, 2016).

14. Wildayana, E. 2013. Palm Oil Farmer Household Behavior in Relation to the Prospect of Sustainability of Contract Plantations in South Sumatra. Dissertation. Sriwijaya University Postgraduate Program. Palembang. 